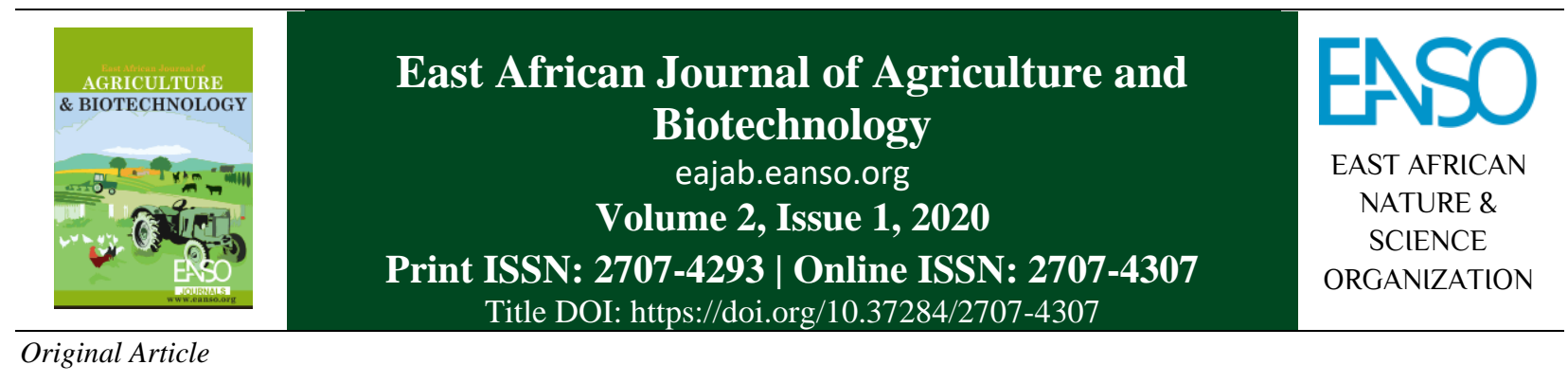

\title{
Senna siamea Seed Provenance of Zimbabwe: A Potential Oleic- and Linoleic-Acid-Rich Dietary Protein and Energy Source for Livestock and Poultry Feeds
}

Dr. Ellis Ayayee, $P h D^{1,2}$, Bayanda Mdoda, $M S c^{1,3} \&$ Prof. Eliton Chivandi, $P h D^{1,4, *}$

${ }^{1}$ University of the Witwatersrand, 7 York Road, Parktown, 2193, Johannesburg, South Africa.

${ }^{2}$ ORCID: https://orcid.org/0000-0002-8107-2414

${ }^{3}$ ORCID: https://orcid.org/0000-0002-7530-3220

${ }^{4}$ ORCID: https://orcid.org/0000-0003-0386-4245

*Author for Correspondence email: Eliton.Chivandi@ wits.ac.za

Article DOI: https://doi.org/10.37284/eajab.2.1.196

\section{Date Published: ABSTRACT}

19 August 2020 In sub-Saharan Africa (SSA), off-veld ruminant livestock and commercial poultry production fail to meet the demand for meat and eggs. Intensified production to

Keywords: meet the demand requires nutritionally balanced feeds. Competition between

Senna siamea, Alternative Feeds,

Fodder Crop,

Nutrients,

Protein,

Energy, humans, livestock and poultry for feed resources present a challenge hence the need for alternative feed resources. Indigenous trees seeds are potential sources of nutrients. Senna siamea, widely distributed in SSA, produces an abundance of seed. We evaluated, by chemical analyses, the potential of hulled (HSSM) and dehulled (DSSM) in S. siamea seed meal to supply nutrients in feeds. DSSM had higher DM, $\mathrm{CP}, \mathrm{EE}$, ash, $\mathrm{P}$ and gross energy $(92.71 \pm 0.08 \%, 47.89 \pm 0.03 \%, 11.39 \pm 0.16 \%$,

Fatty Acids. $6.17 \pm 0.07 \%, 1.01 \pm 0.03 \%$ and $23.13 \pm 0.05 \mathrm{MJ} / \mathrm{kg} \mathrm{DM}$, respectively) content than HSSM $(\mathrm{P}<0.05)$. Amino acids were more concentrated $(\mathrm{P}<0.05)$ in the DSSM. HSSM's CF, NDF, ADF and Ca content was significantly higher $(\mathrm{P}<0.05)$ compared to that of the DSSM. The DM, CP, EE and gross energy (GE) content $(89.48 \pm 0.09 \%, \quad 21.75 \pm 0.09 \%, \quad 4.71 \pm 0.41 \%$, and $20.46 \pm 0.04 \mathrm{MJ} / \mathrm{kg} \mathrm{DM}$, respectively) of the HSSM though lower compared to in DSSM, are within range of conventional plant-derived dietary protein and energy sources for feeds. DSSM's $\mathrm{CP}$ and GE is higher than that of conventional dietary protein and energy sources for feeds. The TSFAs $(27.88 \pm 1.36 \%$ vs $27.53 \pm 0.59 \%)$ and TPUFAs $(50.42 \pm 5.18 \%$ vs $53.42 \pm 2.12 \%$ ) proportion of the HSSM and DSSM, respectively were similar. HSSM $(21.69 \pm 0.18 \%)$ had a significantly higher proportion of TMUFAs than DSSM (19.03 $\pm 0.21 \%)$. DSSM had a higher concentration of the fatty acids per unit mass since it had more than double EE content of the HSSM. In HSSM and DSSM 
palmitic $(19.18 \pm 0.44 \%$ vs $18.63 \pm 0.37 \%)$, oleic $(21.15 \pm 0.09 \%$ vs $18.45 \pm 0.01 \%)$ and linoleic acid (43.35 vs $50.62 \%$ ), respectively were the dominant saturated, monounsaturated and polyunsaturated fatty acids. S. siamea seed meals can potentially be exploited as oleic- and linoleic acid-rich dietary energy and protein sources in livestock and poultry feeds.

\begin{abstract}
APA CITATION
Ayayee, E., Mdoda, B., \& Chivandi, E. (2020). Senna siamea Seed Provenance of Zimbabwe: A Potential Oleic- and LinoleicAcid-Rich Dietary Protein and Energy Source for Livestock and Poultry Feeds. East African Journal of Agriculture and Biotechnology, 2(1), 23-33. https://doi.org/10.37284/eajab.2.1.196
\end{abstract}

\title{
CHICAGO CITATION
}

Ayayee, Ellis, Bayanda Mdoda, and Eliton Chivandi. 2020. "Senna siamea Seed Provenance of Zimbabwe: A Potential Oleicand Linoleic-Acid-Rich Dietary Protein and Energy Source for Livestock and Poultry Feeds". East African Journal of Agriculture and Biotechnology 2 (1), 23-33. https://doi.org/10.37284/eajab.2.1.196.

\section{HARVARD CITATION}

Ayayee, E., Mdoda, B. and Chivandi, E. (2020) "Senna siamea Seed Provenance of Zimbabwe: A Potential Oleic- and LinoleicAcid-Rich Dietary Protein and Energy Source for Livestock and Poultry Feeds", East African Journal of Agriculture and Biotechnology, 2(1), pp. 23-33. doi: 10.37284/eajab.2.1.196.

\section{IEEE CITATION}

E. Ayayee, B. Mdoda, and E. Chivandi, "Senna siamea Seed Provenance of Zimbabwe: A Potential Oleic- and Linoleic-AcidRich Dietary Protein and Energy Source for Livestock and Poultry Feeds”, EAJAB, vol. 2, no. 1, pp. 23-33, Aug. 2020.

\section{MLA CITATION}

Ayayee, Ellis, Bayanda Mdoda, and Eliton Chivandi. "Senna siamea Seed Provenance of Zimbabwe: A Potential Oleic- and Linoleic-Acid-Rich Dietary Protein and Energy Source for Livestock and Poultry Feeds". East African Journal of Agriculture and Biotechnology, Vol. 2, no. 1, August 2020, pp. 23-33, doi:10.37284/eajab.2.1.196.

\section{INTRODUCTION}

Livestock and poultry products (meat, milk and eggs) are important sources of nutrients in human diets. In the developing world, especially in Asia and sub-Saharan Africa (SSA) the demand for these products is increasing at a greater rate compared to that of the developing world (Thornton, 2010). The demand for meat, milk and eggs in SSA and elsewhere in the developing world is expected to double by 2050 (Van Vuren et al., 2009). The increase in demand is premised on increase in the human population, improvement of the socioeconomic statuses of the population, expansion of urban settlements (Thornton, 2010) and the increase in energy intake from the current 200 $\mathrm{kcal} /$ person/day to $400 \mathrm{kcal} /$ person/day (Van Vuren et al., 2009).

In SSA, failure to meet human requirements for meat, milk and eggs is compromising household nutrient and food security. The need to intensify the production of livestock and poultry in order to ensure food security at the household level in SSA has become paramount. However, intensive livestock and poultry production subsist on cereal and legume grains which are staple food crops for human consumption resulting in competition for feed and food resources between livestock and poultry against humans (Delgado, 2005, Pandit et al., 2014). The competition-induced shortages lead to prohibitive livestock and poultry feed costs. The ensuing high feed costs make it costly to intensify livestock and poultry production. Importantly, these high feed costs compromise resource-limited rural and township communities' ability to afford and or even produce animal/poultry-derived products for home consumption (Rosegrant et al., 2009) thus negatively impacting household food security. The human-livestock-poultry competition for food and feed resources militates against the intensification of livestock and poultry product production in order to meet increased and increasing demand (Thornton, 2010; Pelletier and Tyedmers, 2010). A dire need, therefore, exists to develop non-conventional but novel feed crops that can be exploited to meet the needs for 
intensification of livestock and poultry production without the challenge of competition with humans for cereal and legume requirements.

Sub-Saharan Africa is endowed with indigenous fruit-bearing trees whose seeds are largely left to rot in the veld (Chivandi et al., 2011; Chivandi et al., 2015). Exploiting seeds from high yielding indigenous plants/fruit trees with characteristics for domestication could improve the livelihoods of rural households and mitigate against food insecurity (Hughes and Haq, 2003). Such indigenous trees could potentially contribute to the crop-livestock system by becoming feed ingredient sources for livestock and poultry. Furthermore, such novel plants could contribute to the income of rural communities through the collection and marketing of the seeds which would then be exploited as feed resources. An indirect but important benefit will be increased conservation of such trees to the overall improvement of the environment.

Senna siamea (Lam), family Fabaceae, commonly known as the Yellow cassia. It is a medium-sized fast-growing, hardy legume tree widely distributed in tropical SSA where it grows well in the west, east and southern Africa rangelands (Kamagaté et al., 2014). The tree produces an abundance of seeds (Ingweye et al., 2010). Due to its hardiness and ability to thrive in different eco-environments (Okon et al., 1996), S. siamea can potentially be used to reclaim degraded rangelands characterised with poor soil fertility. Its fast growth can be exploited in reforestation programs and possibly contribute as a forage crop in crop-livestock production systems. Currently, S. siamea is only marginally exploited as a fodder crop with its browse (leaves and pods) used in feeding ruminants (Heuzẻ et al., 2019). There is limited evidence of its seed being commercially exploited as a feed resource (Heuzẻ et al., 2019) despite its inherent high crude protein content (Ingweye et al., 2010; Gulewicz et al., 2014). In addition to S. siamea seed's high crude protein content, it is also rich in dietary fibre, carbohydrates and polyunsaturated fats (Gulewicz et al., 2014) thus the potential of its seed as a livestock and poultry feed resource requires further interrogation. However, the chemical nutrient characterisation of $S$. siamea seed provenances in Africa has been confined to small areas such as Nigeria (Ingwye et al., 2010) where its seed is exploited as a source of protein in human diets. Most of the studies on S. siamea have largely focused on the chemical nutrient content of the tree's leaves, petals and bark (Alli-Smith, 2009; Bukar et al., 2009; Kamagaté et al., 2014; Gulewicz et al., 2014). To our knowledge, there is no record of the chemical nutrient characterisation of $S$. siamea seed provenances in Southern Africa. In order to gain buy-in from policymakers in African governments and to qualify for possible integration into the crop-livestock systems of SSA, there is a need for wider chemical nutrient characterisation of $S$. siamea seed provenances in other regions of Africa. Thus, our study evaluated the chemical nutrient composition of $S$. siamea seed provenance harvested from Mapfungautsi Forest Reserve, Gokwe, in northwestern Zimbabwe where no characterisation of the seed has been reported.

\section{MATERIALS AND METHODS}

\section{Senna siamea Seed: Source and Identification}

Fresh S. siamea pods containing ripened seed were collected from virgin lands of Mapfungautsi Forest Reserve, Gokwe, in North West Zimbabwe (Latitude: $19^{\circ} 28^{\prime} 26.5^{\prime}$ South; Longitude: $31^{\circ} 45^{\prime} 14^{\prime}$ East; Altitude: $1007 \mathrm{~m}$ ). The pods were collected from ten randomly selected S. siamea trees. The area from which the seeds were harvested has a predominance of deep Gusu sandy soils derived from granite rocks and is characterised with annual rainfall averaging $819 \mathrm{~mm}$, high temperatures with an annual average of $26{ }^{\circ} \mathrm{C}$ (Gwimbi, 2009). Samples of the pods, seed and leaves of the trees from which the fruit was collected were sent to the C. E. Moss Herbarium (J) of the University of the Witwatersrand and authenticated as Senna simea by Mr. Donald McCallum, a botanist in the herbarium.

\section{Seed Processing and Meal Storage}

The pods were hand-shelled and the seeds (beans) dried in the shade on a clean polythene plastic sheet for 7 days. About half the dried seeds were manually dehulled and the other half was kept unhulled. The respective seeds were then ground into the unhulled and dehulled S. siamea seed meals (HSSM and DSSM, respectively) using a blender (Waring; Lasec Pty Ltd, Johannesburg). Each meal 
was stored in a dark cupboard in an airtight sample bottle pending chemical nutrient determinations.

\section{Chemical Nutrient Assays}

The various nutrient assays were done using analytical grade reagents and chemicals purchased from Sigma Aldrich. The assays were done at the Agricultural Research Council's Irene Analytical Services Laboratories, Pretoria, South Africa. Each assay was done in triplicate.

\section{Determination of the Proximate Components}

The dry matter (DM), ash, crude protein content (CP), ether extract (EE) and crude fibre (CF) of the unhulled and dehulled S. siamea seed meals (HSSM and DSSM, respectively) were determined as described by Association of Analytical Chemists (AOAC, 2005; method numbers 934.01, 942.05, 954.01, 920.39 and 978.10, respectively). Each seed meal's gross energy content value was determined using an MC-1000 Modular calorimeter equipped with a desktop computer and MC1000 software.

\section{Determination of the Meal's' Calcium and Phosphorus Content}

The calcium and phosphorus content of the seed meals were determined as described by Zasoski and Burau (1977). In essence, $0.5 \mathrm{~g}$ of the seed meal sample was mixed with concentrated nitric acid and perchloric acid at $200{ }^{\circ} \mathrm{C}$ to generate the digest solution from which an aliquot was used for the inductively coupled plasma optical emission spectrometric (ICP-OES) determination of calcium and phosphorus. The assay was then done on a Varian Liberty 200 spectrometer (Varian, Perth, Australia) as described by Huang and Schulte (1985).

\section{Determination of the Seed Meals' Detergent Fibre Content}

The neutral detergent fibre (NDF) and acid detergent fibre (ADF) were determined as described by Van Soest et al. (1991). In determining $\mathrm{NDF}$, about $0.5 \mathrm{~g}$ of the seed meal was refluxed for 1 hour in $100 \mathrm{ml}$ of a neutral detergent solution of sodium lauryl sulphate and ethylenediamine-tetraacetic to which alpha-amylase (20 $350 \mathrm{IU} \mathrm{ml}^{-1}$;
Sigma-Aldrich, St Louis, USA) was added. The mixture was then filtered after refluxing for one hour, then dried and weighed. The ADF was determined by refluxing $0.5 \mathrm{~g}$ of the sample for 1hour in acid detergent solution (20 g acetyltrimethyl ammonium bromide dissolved in $1 \mathrm{~L}$ normal $\mathrm{H}_{2} \mathrm{SO}_{4}$ ). The resulting mixture was then filtered and the residue dried and weighed.

\section{Determination of the Meals' Amino Acid Content}

The procedures described by Einarsson et al. (1983) were used in determining the amino acid concentration of each seed meal. In summary, a sample of each seed meal sample was hydrolysed with $6 \mathrm{M} \mathrm{HCl}$ at $110{ }^{\circ} \mathrm{C}$ for 24 hours. Thereafter pre-column fluorescence derivatisation of amino acids was done by reacting them with 9flourenylmethyl chloroformate following which the amino acids were extracted using pentane and separated by gradient elution on a chromatograph. A SpectraSystem P4000 Quaternary highperformance liquid chromatography (HPLC) equipped with a SpectraSystem FL 3000 fluorescence detector and Rheodyne 7125 valve with $20 \mu \mathrm{L}$ injection pump made up the chromatograph. The buffer system which varied from sodium citrate buffer $(\mathrm{pH} 2.95)$ of acetonitrile in the ratio of 70:30 to sodium citrate buffer $(\mathrm{pH}$ 4.5) of methanol-acetonitrile in the ratio of 14: 6 : 70 was used to separate the amino acids. The buffer system was delivered at a flow rate of $1.4 \mathrm{~mL} \mathrm{~min}$ 1. An OmniSper 5 C18 $150 \times 4.6$ analytical column and guard-column were used in the separation of the amino acids. The identification of the amino acids in the chromatogram was done at an excitation wavelength of $264 \mathrm{~nm}$ and an emission wavelength of $340 \mathrm{~nm}$ (Einarsson et al., 1983). A personal computer with a TSP software was used to perform the quantification.

\section{Determination of the Meals' Fatty Acid Content}

The solvent extraction method using a Soxhlet apparatus was used for fat extraction. The methylation of the lipid to produce methyl esters and the subsequent profiling and quantification of individual fatty acids was done as described by Christopherson and Glass (1969). 
East African Journal of Agriculture and Biotechnology, Volume 2, Issue 1, 2020

Article DOI: https://doi.org/10.37284/eajab.2.1.196

\section{Data Analysis}

Data are presented as mean, $\pm \mathrm{SD}$. Data analysis was done using GraphPad Prism version 6 (GraphPad Software, San Diego, California, USA). Means were computed and compared using a t-test. Significance was set at $5 \%$.

\section{RESULTS}

The proximate (DM, CP, EE, CF and ash), NDF, $\mathrm{ADF}, \mathrm{Ca}$ and $\mathrm{P}$ as well as the GE of the seed meals are shown in Table 1. The DM, CP, EE, ash, $\mathrm{P}$ and gross energy $(92.71 \pm 0.08 \%$ vs $89.48 \pm 0.08$, $47.89 \pm 0.03 \%$ vs $21.75 \pm 0.09 \%, 11.39 \pm 0.16 \%$ vs $4.71 \pm 0.41 \%, \quad 6.17 \pm 0.07 \%$ vs $3.45 \pm 0.03 \%$, $1.01 \pm 0.03 \%$ vs $0.41 \pm 0.01 \%$ and $23.13 \pm 0.05 \mathrm{MJ} / \mathrm{kg}$ $\mathrm{DM}$ vs $20.46 \pm 0.04 \mathrm{MJ} / \mathrm{kg} \mathrm{DM}$, respectively) content of the DSSM were significantly higher $(\mathrm{P}<0.05)$ than those of the HSSM. The CF $(6.81 \pm 0.08 \%$ vs $4.30 \pm 0.29 \%)$, NDF $(20.26 \pm 0.30 \%$ vs $8.05 \pm 0.12 \%)$, $\mathrm{ADF}(10.71 \pm 0.12$ vs $2.70 \pm 0.05 \%)$ and $\mathrm{Ca}(0.44 \pm 0.01 \%$ vs $0.26 \pm 0.01 \%)$ content of the HSSM was significantly higher $(\mathrm{P}<0.05)$ compared to that of the DSSM.

Table 1: Proximate, neutral and acid detergent fibre, calcium and phosphorus and gross energy content of unhulled and dehulled $S$. siamea seed meal

\begin{tabular}{llll}
\hline Constituent & Unhulled seed meal & Dehulled seed meal & Sig. level \\
\hline Proximate (\% DM) & & & \\
Dry matter (DM) & $89.48 \pm 0.09^{\mathrm{a}}$ & $92.71 \pm 0.08^{\mathrm{b}}$ & $*$ \\
Crude protein (CP) & $21.75 \pm 0.09^{\mathrm{a}}$ & $47.89 \pm 0.03^{\mathrm{b}}$ & $* *$ \\
Ether extract (EE) & $4.71 \pm 0.41^{\mathrm{a}}$ & $11.39 \pm 0.16^{\mathrm{b}}$ & $* *$ \\
Crude fibre (CF) & $6.81 \pm 0.08^{\mathrm{b}}$ & $4.30 \pm 0.29 \mathrm{a}$ & $*$ \\
Ash & $3.45 \pm 0.03^{\mathrm{a}}$ & $6.17 \pm 0.07^{\mathrm{b}}$ & $*$ \\
Detergent fibre (\% DM) & & & $* .05 \pm 0.12^{\mathrm{a}}$ \\
Neutral detergent fibre & $20.26 \pm 0.30^{\mathrm{b}}$ & $2.70 \pm 0.05^{\mathrm{a}}$ & $* *$ \\
Acid detergent fibre & $10.71 \pm 0.12^{\mathrm{b}}$ & & $*$ \\
Minerals (\% DM) & & $0.26 \pm 0.01^{\mathrm{a}}$ & $* *$ \\
Calcium & $0.44 \pm 0.01^{\mathrm{b}}$ & $1.01 \pm 0.03^{\mathrm{b}}$ & $*$ \\
Phosphorus & $0.41 \pm 0.01^{\mathrm{a}}$ & $23.13 \pm 0.05^{\mathrm{b}}$ & $*$ \\
Energy (MJ/kg DM) & & & \\
Gross energy & $20.46 \pm 0.04^{\mathrm{a}}$ & & \\
\hline a,b Means with different superscripts are significantly different at $P<0.05 ; * P<0.05 ; * P<0.01 ;$ Data \\
presented as Mean \pm SD; $n=3$.
\end{tabular}

Table 2 shows the amino acid content of the meals. Essential and non-essential amino acid concentration was higher $(\mathrm{P}<0.05)$ in the DSSM. The TSFAs $(27.88 \pm 1.36 \%$ vs $27.53 \pm 0.59 \%)$ and TPUFAs $\quad(50.42 \pm 5.18 \%$ vs $53.42 \pm 2.12 \%)$ proportion of the HSSM and DSSM, respectively were similar, HSSM $(21.69 \pm 0.18 \%)$ had a significantly higher proportion of TMUFAs than $\operatorname{DSSM}(19.03 \pm 0.21 \%)$.

Table 2: Amino acid content of unhulled and dehulled $S$. siamea seed meal

\begin{tabular}{|c|c|c|c|}
\hline Amino acid (g/100g DM) & Unhulled seed meal & Dehulled seed meal & Sig level \\
\hline Alanine & $1.53 \pm 0.01^{\mathrm{a}}$ & $1.53 \pm 0.01^{\mathrm{a}}$ & $\mathrm{ns}$ \\
\hline Arginine & $2.22 \pm 0.02^{\mathrm{a}}$ & $4.89 \pm 0.07^{b}$ & $*$ \\
\hline Aspartic acid & $1.50 \pm 0.00^{\mathrm{a}}$ & $3.00 \pm 0.04^{\mathrm{b}}$ & $*$ \\
\hline Glutamic acid & $4.45 \pm 0.10^{\mathrm{a}}$ & $9.55 \pm 0.09^{b}$ & $* *$ \\
\hline Glycine & $0.91 \pm 0.02^{\mathrm{a}}$ & $1.86 \pm 0.02^{\mathrm{b}}$ & $* *$ \\
\hline Histidine & $0.54 \pm 0.07^{a}$ & $0.86 \pm 0.15^{b}$ & $*$ \\
\hline Hydroxyproline & $0.07 \pm 0.02^{\mathrm{b}}$ & $0.04 \pm 0.02^{\mathrm{a}}$ & $*$ \\
\hline Isoleucine & $0.69 \pm 0.00^{\mathrm{a}}$ & $1.46 \pm 0.02^{\mathrm{b}}$ & $* *$ \\
\hline
\end{tabular}


East African Journal of Agriculture and Biotechnology, Volume 2, Issue 1, 2020

Article DOI: https://doi.org/10.37284/eajab.2.1.196

\begin{tabular}{|c|c|c|c|}
\hline Amino acid (g/100g DM) & Unhulled seed meal & Dehulled seed meal & Sig level \\
\hline Leucine & $1.21 \pm 0.00^{\mathrm{a}}$ & $2.58 \pm 0.03^{\mathrm{b}}$ & * \\
\hline Lysine & $1.40 \pm 0.02^{\mathrm{a}}$ & $2.94 \pm 0.09^{b}$ & $* *$ \\
\hline Phenylalanine & $0.80 \pm 0.02^{\mathrm{a}}$ & $1.69 \pm 0.01^{b}$ & $* *$ \\
\hline Proline & $0.69 \pm 0.02^{\mathrm{a}}$ & $1.42 \pm 0.02^{b}$ & $* *$ \\
\hline Serine & $0.82 \pm 0.02^{\mathrm{a}}$ & $1.65 \pm 0.03^{b}$ & $* *$ \\
\hline Threonine & $0.59 \pm 0.02^{\mathrm{a}}$ & $1.19 \pm 0.02^{\mathrm{b}}$ & ** \\
\hline Tyrosine & $0.57 \pm 0.02^{\mathrm{a}}$ & $1.13 \pm 0.01^{\mathrm{b}}$ & $*$ \\
\hline Valine & $0.80 \pm 0.02^{\mathrm{a}}$ & $1.60 \pm 0.03^{b}$ & $* *$ \\
\hline Total & 18.18 & 37.83 & \\
\hline
\end{tabular}

${ }^{a, b}$ Means with different superscripts are significantly different at $P<0.05 ; * P<0.05$, ns - not significantly different, $* * P<0.01$; Data presented as Mean $\pm S D ; n=3$.

Table 3 shows the fatty acid content of the meals. DSSM had a higher concentration of the fatty acids per unit mass by virtue of it having more than double EE content of the HSSM. In HSSM and DSSM the dominant saturated, monounsaturated and polyunsaturated fatty acids were palmitic $(19.18 \pm 0.44 \%$ vs $18.63 \pm 0.37 \%)$, oleic $(21.15 \pm 0.09 \%$ vs $18.45 \pm 0.01 \%)$ and linoleic acid (43.35 vs $50.62 \%)$, respectively.

Table 3: Fatty acid profile of unhulled and dehulled $S$. siamea seed meal

\begin{tabular}{llll}
\hline Fatty acid (\%) & Unhulled seed meal & Dehulled seed meal & Sig. level \\
\hline Saturated fatty acid & & & \\
C 12:0 (lauric acid) & $0.02 \pm 0.01^{\mathrm{a}}$ & $0.01 \pm 0.01^{\mathrm{a}}$ & $\mathrm{ns}$ \\
C 14:0 (myristic acid) & $0.07 \pm 0.02^{\mathrm{a}}$ & $0.07 \pm 0.02^{\mathrm{a}}$ & $\mathrm{ns}$ \\
C 15:0 (pentadecanoic acid) & $0.04 \pm 0.01^{\mathrm{a}}$ & $0.13 \pm 0.04^{\mathrm{b}}$ & $* *$ \\
C 16:0 (palmitic acid) & $19.18 \pm 0.44^{\mathrm{a}}$ & $18.63 \pm 0.37^{\mathrm{a}}$ & $\mathrm{ns}$ \\
C 17:0 (margaric acid) & $0.13 \pm 0.01^{\mathrm{a}}$ & $0.14 \pm 0.01^{\mathrm{a}}$ & $\mathrm{ns}$ \\
C 18:0 (stearic acid) & $6.35 \pm 0.68^{\mathrm{a}}$ & $6.77 \pm 0.03^{\mathrm{a}}$ & $\mathrm{ns}$ \\
C 20:0 (arachidic acid) & $1.07 \pm 0.15^{\mathrm{a}}$ & $1.13 \pm 0.03^{\mathrm{a}}$ & $\mathrm{ns}$ \\
C 21:0 (heneicosanoic acid) & $0.06 \pm 0.01^{\mathrm{a}}$ & $0.07 \pm 0.01^{\mathrm{a}}$ & $\mathrm{ns}$ \\
C 24:0 (lignoceric acid) & $0.96 \pm 0.04^{\mathrm{b}}$ & $0.58 \pm 0.11^{\mathrm{a}}$ & $* *$ \\
TSFAs & $27.88 \pm 1.36^{\mathrm{a}}$ & $27.53 \pm 0.59^{\mathrm{a}}$ & $\mathrm{ns}$ \\
Monounsaturated fatty acid & & & \\
C 15:1 (pentadecenoic acid) & $\mathrm{nd}$ & $0.05 \pm 0.02^{\mathrm{a}}$ & $\mathrm{ns}$ \\
C 16:1 (palmitoleic acid) & $0.21 \pm 0.02^{\mathrm{a}}$ & $0.17 \pm 0.01^{\mathrm{a}}$ & $\mathrm{ns}$ \\
C 17:1 (heptadecenoic acid) & $0.06 \pm 0.01^{\mathrm{a}}$ & $0.05 \pm 0.01^{\mathrm{a}}$ & $* *$ \\
C 18:1n9c (oleic acid) & $21.15 \pm 0.09^{\mathrm{b}}$ & $18.45 \pm 0.10^{\mathrm{a}}$ & \\
C 18:1n9t (elaidic acid) & $\mathrm{nd}$ & $0.04 \pm 0.01$ & $\mathrm{~ns}$ \\
C 20:1 (11-eicosenoic acid) & $0.22 \pm 0.04^{\mathrm{a}}$ & $0.21 \pm 0.02^{\mathrm{a}}$ & $\mathrm{ns}$ \\
C 22:1n9 (erucuc acid) & $0.03 \pm 0.02^{\mathrm{a}}$ & $0.05 \pm 0.04^{\mathrm{a}}$ & $*$ \\
TMUFAs & $21.69 \pm 0.18^{\mathrm{b}}$ & $19.03 \pm 0.21^{\mathrm{a}}$ & $\mathrm{ns}$ \\
Polyunsaturated fatty acid & & & $\mathrm{n}$ \\
C 18:2n6c (linoleic acid) & $48.24 \pm 4.92^{\mathrm{a}}$ & $50.98 \pm 2.01^{\mathrm{a}}$ & $\mathrm{ns}$ \\
C 18:2n6t (linolelaidic acid) & $0.04 \pm 0.01^{\mathrm{a}}$ & $0.05 \pm 0.01^{\mathrm{a}}$ & $\mathrm{ns}$ \\
C 18:3n3 (a-linolenic acid) & $0.60 \pm 0.07^{\mathrm{a}}$ & $0.62 \pm 0.02^{\mathrm{a}}$ & $\mathrm{ns}$ \\
C 18:3n6 ( $\gamma$-linolenic acid) & $0.02 \pm 0.01^{\mathrm{a}}$ & $0.04 \pm 0.02^{\mathrm{a}}$ & $\mathrm{ns}$ \\
C 20:2 (eicosadienoic acid) & $0.04 \pm 0.01^{\mathrm{a}}$ & $0.05 \pm 0.01^{\mathrm{a}}$ & $\mathrm{ns}$ \\
C20:5n3 (eicosapentaenoic acid) & $1.32 \pm 0.14^{\mathrm{a}}$ & $1.49 \pm 0.02^{\mathrm{a}}$ & $\mathrm{n}$ \\
C 22:2 (docosadienoic acid) & $0.16 \pm 0.02^{\mathrm{a}}$ & $0.19 \pm 0.03^{\mathrm{a}}$ & \\
\hline & & & \\
\end{tabular}




\begin{tabular}{llll}
\hline Fatty acid (\%) & Unhulled seed meal & Dehulled seed meal & Sig. level \\
\hline TPUFAs & $50.42 \pm 5.18^{\mathrm{a}}$ & $53.42 \pm 2.12^{\mathrm{a}}$ & $\mathrm{ns}$ \\
Trans FA & $0.04 \pm 0.02^{\mathrm{a}}$ & $0.04 \pm 0.01^{\mathrm{a}}$ & $\mathrm{ns}$ \\
Cis fats & $69.52 \pm 7.07^{\mathrm{a}}$ & $69.25 \pm 0.91^{\mathrm{a}}$ & $\mathrm{ns}$ \\
Omega-3 fats & $1.95 \pm 0.22^{\mathrm{a}}$ & $2.09 \pm 0.01^{\mathrm{a}}$ & $\mathrm{ns}$ \\
Omega-6 fats & $48.41 \pm 4.94^{\mathrm{a}}$ & $50.70 \pm 1.03^{\mathrm{a}}$ & $\mathrm{ns}$ \\
Omega-9 fats & $21.20 \pm 2.18^{\mathrm{a}}$ & $18.69 \pm 0.01^{\mathrm{a}}$ & $\mathrm{ns}$ \\
EPA (eicosapentaenoic acid ) & $1.32 \pm 0.15^{\mathrm{a}}$ & $1.49 \pm 0.02^{\mathrm{a}}$ & $\mathrm{ns}$ \\
TPUFAs: TSFAs & $1.80: 1$ & $1.93: 1$ & \\
n3PUFA: n6PUTA & $0.04: 1$ & $0.04: 1$ & \\
\hline
\end{tabular}

${ }^{a, b}$ Within row means with different superscripts are significantly different at $P<0.05$, $* * P<0.01 ; n s-n o t$ significantly different; $n d$-not detected; EPA-Eicosapentaenoic acid, TSFAs - Total saturated fatty acids, TMUFAs - Total monounsaturated fatty acids, TPUFAs - Total polyunsaturated fatty acids, $n=3$; Data presented as mean $\pm S D$.

\section{DISCUSSION}

We sought to characterise the proximate (DM, CF, $\mathrm{CP}$, EE and ash), gross energy, calcium and phosphorus, NDF and ADF, amino acid and fatty acid content of the $S$. siamea seed provenance from Zimbabwe and evaluate its potential as a source of nutrients in livestock and poultry feeds. We determined the chemical nutrient content of unhulled (HSSM) and dehulled (DSSM) S. siamea seed meal. The CP and GE content of the meals ranged from $21.75 \pm 0.09 \%$ to $47.89 \pm 0.03 \%$ and $20.46 \pm 0.04 \mathrm{MJ} / \mathrm{kg} \mathrm{DM}$ and $23.13 \pm 0.05 \mathrm{MJ} / \mathrm{kg} \mathrm{DM}$ for the HSSM and DSSM, respectively. The DSSM had about more than twice the EE content of the HSSM. Both meals' fatty acid profiles were dominated by TPUFAs and TSFAs making up about $50 \%$ and $28 \%$ of the seed meals' oil/lipid content, respectively. Oleic and linoleic are the dominant fatty acids in the seed meals.

The determination of the proximate and amino acid composition are critical in the evaluation of the nutritional quality of potential feed resources. In intensive livestock and poultry production, maize meal and soybean meal (SBM) are the major dietary energy and protein sources, respectively, in feeds. Yellow maize, one of the global cereal grains largely used in livestock and poultry feeds, typically contains $8-10 \%$ protein, $4 \%-5 \%$ oil/fat, $1.4 \%$ ash, $71.7 \%$ starch (Watson, 2003; Prasanthi et al., 2017) and about 17.5 to $18 \mathrm{MJ} / \mathrm{kg} \mathrm{DM}$ gross energy (Bhuiyan et al., 2010). Hexane-extracted SBM's CP content is about $44 \%$ though it can range from $44 \%$ to $49 \%$ (Banaszkiewicz, 2011) depending on cultivar. Sunflower seed meal
(SFSM) which contains $28 \%-34 \%$ CP when partially dehulled and about $41 \% \mathrm{CP}$ when fully dehulled and canola seed meal (CSM) with about 40\% CP (Lardy and Anderson, 2002) constitute other major plant-derived dietary sources for feeds. We report a CP content of $21.75 \%$ and $47.89 \%$ and GE content of $20.46 \mathrm{MJ} . \mathrm{kg} \mathrm{DM}$ and $23.13 \mathrm{MJ} / \mathrm{kg}$ DM in the hulled and dehulled S. siamea seed meals, respectively. While the CP of the hulled $S$. siamea seed meal is lower than that of SFSM, CSM and SBM, it is adequate to meet the nutritional requirements of ruminants. Thus hulled $S$. siamea seed meal can be a potential protein source in ruminant animal feeds.

The comparatively higher fibre (CF, NDF and $\mathrm{ADF}$ ) could be of great value to ruminant nutrition as the fibre can be fermented by rumen resident microbes to generate the volatile fatty acids (VFAs) acetic, butyric, propionic, iso-valeric and valeric acid. On metabolism, the VFAs generate energy which ruminants can utilise thus less cereal grain would be required in the ruminant feeds especially where pen fattening is practised. Additionally, the higher $\mathrm{CF}, \mathrm{NDF}$ and ADF besides being a source of energy, also can provide dietary fibre necessary for gastrointestinal health. Our findings show that the dehulling of the $S$. siamea seed resulted in more than a $100 \%$ increase in $\mathrm{CP}$ to $47.89 \%$ which is higher than the mean CP content of SBM and CSM. This is of significance as it shows that dehulled $S$. siamea seed meal has a greater protein and indeed amino acid concentration per unit mass than the conventionally used SBM and CSM. It, therefore, means less $S$. siamea seed meal would be required in livestock and poultry feeds which translates to 
reduced feed cost since the protein component of feeds is the most expensive component (Iji et al., 2017). Our findings show that dehulling S. siamea seed substantially increased the seed's nutrient density, especially $\mathrm{CP}$, both non-essential and essential amino acids, $\mathrm{P}$ and $\mathrm{GE}$ which were masked by the fibre fraction in its seed hull. Monogastric animals and poultry species, especially broiler chicken are poor utilisers of fibrous feeds. Thus, due to its lower fibre content, dehulled S. siamea seed meal could be an ideal dietary protein source in monogastric livestock and poultry feeds.

Both the hulled (HSSM) and dehulled (DSSM) $S$. siamea seed meal had GE content higher than that of maize. Maize, a major dietary energy source in feeds, constitutes about $65 \%-70 \%$ of monogastric livestock and poultry feeds (Panda et al., 2014). Due to their high mean GE energy values, both HSSM and DSSM can provide a substantial portion of the energy component of livestock and poultry feeds. Therefore, their use as feed ingredients could potentially reduce the maize component (energy source) in the feeds that might translate into cheaper feeds and reduced competition for maize between humans and the livestock and poultry feed industry. Compared to maize which has a fat content of $4 \%$ to 5\% (Watson, 2003), the hulled and dehulled $S$. siamea seed meals had $6 \%$ and $11 \%$ fat, respectively. Fat has a high energy density compared to carbohydrates. We thus contend that the higher GE content of the S. siamea seed meals compared to that of maize meal could be due to the former's higher fat content.

It has been demonstrated that dietary and ingredient fatty acid profile is closely mirrored in the livestock and poultry (meat, eggs and milk) products lipid profile (Butler et al., 2019). In our findings, we report the $S$. siamea seed meals oil to have a preponderance of oleic (18.45\% to $21.15 \%)$ and linoleic acid (43.35\% to $50.62 \%)$. We, therefore, contend that the use of $S$. siamea seed meals as feed ingredients livestock and poultry feeds can mediate the production of eggs and meat with higher concentrations of oleic acid (OA) and linoleic acid (LA). Oleic acid (OA), a monounsaturated fatty acid, exhibits hypocholesterolaemic activity (Haim et al., 2012) and antioxidant activity (Wei et al., 2016). It also has high oxidative stability (Ali et al.,
2016). Linoleic acid (LA), is an essential fatty acid, has with health beneficial activities and necessary for normal prenatal and early postnatal development of the human brain (Harris and Baack; 2015; Taha, 2020). Thus, the use of S. siamea seed meals as feed ingredients could result in the fortification and production of livestock and poultry products of a higher nutritional status with a longer shelf life.

\section{CONCLUSION}

The Zimbabwean S. siamea provenance seed meals can potentially be exploited as oleic- and linoleic acid-rich dietary energy and protein sources in livestock and poultry feeds. Importantly, they can potentially be used to improve the nutrient status, especially the OA and LA acid content, of eggs and meat.

\section{ACKNOWLEDGEMENTS}

We wish to thank the National Research Foundation for providing a research grant that partfunded the study. The Agricultural Research Council's Animal Production Institute, South Africa, is thanked for providing the laboratory platforms for the various assays done.

\section{REFERENCES}

Alli-Smith, Y. R. (2009). Determination of chemical composition of Senna-siamea (cassia leaves). Pakistan Journal of Nutrition, 8(2), 119-121.

Ali, S., Chatha, S. A. S., Ali, Q., Hussain, A. I., Hussain, S. M. \& Perveen, R. (2016). Oxidative stability of cooking oil blend stabilized with leaf extract of Eucalyptus citriodora. International Journal of Food Properties, 19(7), 1556-1565. Doi: 10.1080/10942912.2015.1047514

Association of Official Analytical Chemists. (2005). Official Methods of Analysis. Washington, DC, USA: Association of Official Analytical Chemists.

Banaszkiewicz, T. (2011). Nutritional value of soyabean meal. IntechOpen. DOI: $10.5772 / 23306$. 
Bhuiyan, M. M., Islam, A. F. \& Iji, P. A. (2010). Variation in nutrient composition and structure of high-moisture maize dried at different temperatures. South African Journal of Animal Science, 40(3), 190-197.

Bukar, A., Mukhtar, M. D., \& Hassan, A. S. (2009). Phytochemical screening and antibacterial activity of leaf extracts of Senna Siamea (Lam) on pseudomonas aeruginosa. Bajoye Journal of Pure and Applied Sciences, 2(1), 139-142.

Butler, G., Stergiadis, S., Chatzidimitriou, E., Franceschin, E., Davis, H.R., Leifert, C., \& Steinshamn, H. (2019). Differing responses in milk composition from introducing rapeseed and naked oats to conventional and organic dairy diets. Scientific Reports, 9(5), 1-12. Doi: 10.1038/s41598-019-44567-8.

Chivandi, E., Davidson, B., Pretorius, B., \& Erlwanger, K. (2011). Proximate, mineral, amino acid, fatty acid, vitamin E, phytate phosphate and fibre composition of Mimusops zeyheri (Red Milkwood) seed. International Journal of Food Science and Technology, 46(10), 555-560.

Chivandi, E., Mukonowenzou, N., Nyakudya, T., \& Erlwanger, K. (2015). Potential of indigenous fruit bearing trees to curb malnutrition, improve household food security, income and community health food security, income and community health in Sub-Saharan Africa: a review. Food Research International, 76(4), 980-985. Doi: 10.1016/j.foodres.2015.06.015.

Christopherson, S. W., \& Glass, R. L. (1969). Preparation of milk fat methyl esters by alcoholysis in an essentially nonalcoholic solution. Journal of Dairy Science, 52(8), 1289-1290.

Delgado, C. (2005). Rising demand for meat and milk in developing countries: implications for grassland -based livestock production. In: D. A. McGilloway (Eds), Grassland: A Global Resource. (pp. 29-39). The Netherlands: Wageningen, Academic Publishers.

Einarsson, S., Josefsson, B., \& Lagerkvist, S. (1983). Determination of amino acids with 9- fluorenylmethyl chloroformate and reversedphase high-performance liquid chromatography. Journal of Chromatography, 282(A), 609-618. Doi: 10.1016/S00219673(00)91638-8.

Gulewicz, P., Martinez-Villaluenga, C., Kasprowicz-Potocka, M., \& Frias, J. (2014). Non-nutritive compounds in Fabaceae family seeds and the improvement of their nutritional quality by traditional processing - a review. Polish Journal of Food Nutrition Sciences, 64(2), 75-89. Doi: 10.2478/v10222-012-00989.

Gwimbi, P. (2009). Cotton farmers' vulnerability to climate change in Gokwe District (Zimbabwe): impact and influencing factors. JÀMBÁ: Journal of Disaster Risk Studies, 2(2), 81-92. Doi: 10.4102/jamba.v2i2.17.

Haim, D., Valenzuela, A., Brañes, M. C., Fuenzalida, M., \& Videla, L. A. (2012). The oleic acid esterification of policosanol increases its bioavailability and hypocholesterolemic action in rats. Grasas y Aceites, 63(4), 345-354. Doi: $10.3989 /$ gya010612.

Harris, W. S., \& Baack, M. L. (2015). Beyond building better brains: Bridging the decosahexaenoic acid gap of prematurity. Journal of Perinatology, 35(1), 1-7. https://doi.org/10.1038/jp.2014.195.

Heuzẻ, V., Hassoun, T.G., \& Lebas, F. (2019). Siamese senna (Senna siamea). Feedipedia, a programme by INRA, CIRAD, AFZ and FAO. https://www.feedipedia.org/node/323 (accessed May 10, 2020).

Huang, C.L., \& Schulte, E.E. (1985). Digestion of plant tissue for analysis by ICP emission spectroscopy. Communications in Soil Science and Plant Analysis, 16(9), 943-958. Doi: 10.1080/00103628509367657.

Hughes, A., \& Haq, N. (2003). Promotion of indigenous fruit tress through improved processing and marketing in Asia. The International Forestry Review, 5(2), 176-181. 
Available

at: https://www.jstor.org/stable/43739892.

Iji, P., Togyani, M., Ahiwe, E., \& Omede, A.A. (2017). Alternative sources of protein for poultry nutrition. In book: Achieving sustainable production of poultry meat, 2 , pp 237-269. Doi: 10.19103/AS.2016.0011.13.

Ingweye, J. N., Kailo, G. A., Ubua, J. A., \& Effiong, G. S. (2010). The potential of the lesser known Nigerian legume, Senna siamea a plant protein source. Australian Journal of Basic and Applied Sciences, 4(8), 2222-2231.

Kamagate, M., Koffi, C., Kouame, N. M., Akoubet, A., Yao, N. A. R., \& Die-Kakou, H. M. (2014). Ethnobotany, phytochemistry, pharmacology and toxicology profiles of Cassia siamea Lam. The Journal of Phytopharmacology, 3(1), 5776.

Lardy, P. G., \& Anderson, V. (2002). Canola and sunflower meal in beef cattle diets. The Veterinary Clinics of North American Food and Animal Practice, 18(2), 327-338. Doi: 10.1016/s0749-0720(02)00018-x.

Okon, E. I., Osonubi, O., \& Sanginga, N. (1996). Vesicular-arbuscular mycorrhiza effects on Gliricidia sepium and Senna siamea in a fallowed alley cropping system. Agroforestry Systems, 33(2), 165-175. Doi: 10.1007/BF00213648.

Panda, A. K., Zaidi, P. H., Rama Rao, S. V., \& Raju, M. V. L. N. (2014). Efficacy of quality protein maize in meeting energy and essential amino acid requirements in broiler chicken production. Journal of Applied Animal Research, 42(2), 133-139. doi: $10.1080 / 09712119.2013 .822812$

Pandit, B. H., Shrestha, K. K., \& Bhattarai, S. (2014). Sustainable local livelihoods through enhancing agroforestry system in Nepal. Journal of Forest and Livelihood, 12(1), 47-63.

Pelletier, N., \& Tyedmers, P. (2010). Forecasting potential global environmental costs of livestock production 2000-2050. Proceedings of the National Academy of Sciences, 107(43), 18371-18374. Doi: 10.1073/pnas.1004659107.

Prasanthi, P.S., Naveena, N., Vishrivardhana-Rao, M., \& Bhaskarachary, K. 2017. Compositional variability in corn after processing. Journal of Food Science and Technology, 54(4), 10801090. Doi: 10.1007/s13197-017-2547-2.

Rosegrant, M. W., Ringler, C., Sulser, T.B., Ewing, M., Palazzo, A., \& Zhu, T. (2009). Agriculture and food security under global change: prospect for 2025/2050. Background paper written in support of the CGIAR Strategy and Results Framework. Washington, DC-USA: IFPRI.

Tara, A. Y. (2020). Linoleic acid-good or bad for the brain? NPJ Science of Food, 4(1), 1-6. Doi: 10.1038/1538-019-0061-9.

Thornton, P. K. (2010). Livestock production: recent trends, future prospects. Philosophical Transactions of the Royal Society B: Biological Sciences, 365(1554), 2853-2867. Doi: 10.1098/rstb.2010.0134.

Van Soest, P.J., Robertson, J.B., \& Lewis, B.A. (1991). Methods for dietary fiber, neutral detergent fiber, and nonstarch polysaccharides in relation to animal nutrition. Journal of Dairy Science, 74(10), 3583-3597. Doi: 10.3168/jds.S0022-0302(91)78551-2.

Van Vuren, D. P., Van Ochola, W.O., Riha, S., Giampietro, M., \& Ginzo, H.l. (2009). Outlook on agricultural change and its drivers. In: B.D. McIntyre, H.R. Herren, J. Wakhungu and R. T. Watson (Eds, pp 225-305). Agriculture at a crossroads. Washington, DC-USA: Island Press.

Watson, S. A. (2003). Description, development, structure and composition of the corn kernel. In: White, J. and Johnson C. ( $2^{\text {nd }}$ Ed.) Corn: Chemistry and Technology (pp: 69-101). St. Paul, USA: American Association of Cereal Chemists.

Wei, C. C., Yen, P. L., Chang, S. T., Cheng, P. L., Lo, Y. C., \& Liao, V. H. C. (2016). Antioxidative activities of both oleic acid and 
East African Journal of Agriculture and Biotechnology, Volume 2, Issue 1, 2020

Article DOI: https://doi.org/10.37284/eajab.2.1.196

Camellia tenuifolia seed oil are regulated by the transcription factor DAF-16/FOXO in Caenorhabditis elegans. PLoS One, 11(6), e0157195.

Doi: 10.1371/journal.pone.0157195.

Zasoski, R. J., \& Burau, R. (1977). A rapid nitricperchloric acid digestion method for multielement tissue analysis. Communications in Soil Science and Plant Analysis, 8(5), 425-436. 